\title{
METHODS
}

UDC 543.542:543.544

doi: https://doi.org/10.15407/ubj89.04.077

\section{DETERMINATION OF THE MAJOR COMPOUNDS IN THE EXTRACT OF THE SUBTERRANEAN TERMITE Macrotermes gilvus HAGEN DIGESTIVE TRACT BY GC-MS METHOD}

\author{
N. SUBEKTI ${ }^{1 *}$, F. FIBRIANA ${ }^{2}$, P. WIDYANINGRUM ${ }^{1}$, M. ADFA ${ }^{3}$ \\ ${ }^{1}$ Department of Biology, Faculty of Mathematics and Natural Sciences, \\ Semarang State University, Indonesia; \\ *e-mail: nikensubekti@mail.unnes.ac.id; \\ ${ }^{2}$ Department of Integrated Sciences, Faculty of Mathematics and Natural \\ Sciences, Semarang State University, Indonesia; \\ e-mail: fibriana.f@mail.unnes.ac.id; \\ ${ }^{3}$ Department of Chemistry, Faculty of Mathematics and Natural Sciences, \\ Bengkulu University, Indonesia; morinaadfa@yahoo.com
}

Degradation of woody components by termites is associated with symbionts inside their digestive tract. In this study, the major compounds were determined in the extract of the termite guts by GC-MS method. Macrotermes gilvus Hagen (worker caste) termites were collected and their dissected guts underwent methanol extraction. It was found that the gut of the termites has an alkaline environment ( $\mathrm{pH} 8.83 \pm 0.31$ ) that supports the digestion of lignocellulose biomass and also helps to solubilize phenolic and recalcitrant compounds resulting from the depolymerization of woody components. The GC-MS analysis showed that termite guts contained hydrophobic organosilicon components including dodecamethylcyclohexasiloxane, tetradecamethylcyclohexasiloxane, hexadecamethylcyclooctasiloxane, and octasiloxane, 1,1,3,3,5,5,7,7,9,9,11,11,13,13,15,15-hexadecamethyl. The guts also contained a phytosterol, which was identified as $\beta$-sitosterol. Further analysis of these water-insoluble compounds is needed to reveal their importance in termite digestion.

Key word s: Macrotermes gilvus Hagen, woody material degradation, termite guts, GC-MS method.

$\mathrm{T}$ ermites are well-studied social insects that consume lignocellulose and soil materials. Their gut comprises five compartments, which are differentiated by $\mathrm{pH}$, amounts of lignocellulose enzymes, and levels of oxygen and hydrogen gasses [1]. The polymer-feeding behavior of termites is intensely supported by the microbial community that exists in their gut [2]. Termites possess a twotiered enzyme system, which includes the termites' digestive enzymes and the microbial community enzymes. The two types of enzymes work together to degrade the plant polymers, break down the lignocellulose, and detoxify plant secondary metabolites; interestingly, they also provide enzyme inhibition
$[3,4]$. The digestion of the lignocellulosic materials in the termite gut involves three main stages: (1) hydrolysis; (2) oxidation, fermentation, or both; and (3) acetogenesis, methanogenesis, or both [5].

The hypoxic periphery of the termites' digestive tract has been found to be inhabited by prokaryotic species that consume $\mathrm{O}_{2}$, resulting in anoxic conditions in the gut. However, aerobic bacteria are also found in the gut. It is therefore reasonable to expect that microbial community members have multiple ecological functions, especially given their ubiquitous presence in different termite species $[6,7]$.

The subterranean termite Macrotermes gilvus Hagen is an abundant species in Indonesia. Owing to

(C) 2017 Niken Subekti et al. This is an open-access article distributed under the terms of the Creative Commons Attribution License, which permits unrestricted use, distribution, and reproduction in any medium, provided the original author and source are credited. 
its abundance and its consumption of woody materials, it is an especially destructive and costly species of termite. Nevertheless, their digestion process in utilizing the wooden structures is interesting, especially in the context of the biofuels and biomaterials industries $[8,9]$. The unique digestive system of termites features digestive tract enzymes as well as microfauna symbionts. The two-tiered system makes the termite digestion process complex and difficult to study. The goal of this research was to analyze the chemical properties of the termite gut, where the enzymatic degradation of woody particles results in the depolymerization of lignocellulose and cellulose components [8-10]. An additional objective of this research was to use gas chromatography-mass spectrometry (GC-MS) to characterize the biochemical compounds arising from woody plant material degradation in the termite gut. Biochemical compound information obtained from this study can be used as the additional knowledge for the results of woody materials enzymatic degradation in termite gut, especially for further research on biofuels and biomaterials manufacturing.

\section{Materials and Methods}

Collection of Termites. Macrotermes gilvus worker termites were collected from the area of Semarang State University, Indonesia. After collection in a clean bottle, termites were treated with $70 \%$ ethanol and washed with sterilized distilled water.

Termite Gut pH Profiles. Termites were carefully dissected, after which the guts were immediately crushed and placed in a small glass chamber with insect Ringer's solution solidified with $0.5 \%$ agarose $[6,11]$. $\mathrm{pH}$ was measured using a microelectrode, and the measurement was carried out at ambient temperatures. The $\mathrm{pH}$ measurement was performed in triplicate.

Termite Gut Extraction and GC-MS. Termite guts (approximately $10 \mathrm{~g}$ ) underwent chemical extraction with $100 \mathrm{ml}$ of methanol. Ultrasonication was subsequently performed for $15 \mathrm{~min}$ to homogenize the guts. Afterward, the homogenized guts were centrifuged at $10,000 \times \mathrm{g}$ for $5 \mathrm{~min}$. The supernatant was then injected into a GC-MS system using Agilent 6890N (Agilent Tech., Palo Alto, CA, USA) and JMS-GC mate II (JEOL Inc., Peabody, MA, USA) equipment in which the column was a fused silica capillary (5\% diphenyl and 95\% dimethyl polysiloxane). The Elite column-5ms was $60 \mathrm{~m} \times 0.25 \mathrm{~mm}$, with a film thickness of $0.25 \mu \mathrm{m}$. Helium was used as the carrier gas (Alpha gaz2, Air Liquide, Paris, France) at a constant flow rate of $1 \mathrm{ml} \cdot \mathrm{min}^{-1}$. Injection was done in the splitless mode for $0.5 \mathrm{~min}$ and then at a split flow rate of $50 \mathrm{ml} \cdot \mathrm{min}^{-1}$. First, $0.5 \mu \mathrm{l}$ was injected at $250{ }^{\circ} \mathrm{C}$. The oven was programmed at $35^{\circ} \mathrm{C}(8 \mathrm{~min})$ to $345^{\circ} \mathrm{C}$ (at the rate of $5{ }^{\circ} \mathrm{C} \mathrm{min}^{-1}$ ), after which the temperature remained stable at $345^{\circ} \mathrm{C}$ for $10 \mathrm{~min}$. Mass spectrometry was performed by electron ionization at $70 \mathrm{eV}$. The temperatures of the ion trap and the transfer line were set to $250^{\circ} \mathrm{C}$ and $330{ }^{\circ} \mathrm{C}$, respectively. Detection was done in scan mode (ions of $20-500 \mathrm{~m} / \mathrm{z}$ ), and analysis started $10 \mathrm{~min}$ after the injection. Compound spectra were identified through comparison with standard compounds.

\section{Results and Discussion}

The $\mathrm{pH}$ measurements showed that the whole guts of termites were alkaline. The gut of $M$. gilvus Hagen had an average $\mathrm{pH}$ of $8.83 \pm 0.31$. After extraction of the termite guts, GC-MS was performed to determine their chemical components. The GCMS spectrum showed 12 main peaks (Figure), which corresponded to 12 main components in the termite guts. However, we found five major compounds among 12 main components found in termite guts. The compounds detected are shown in Table.

A symbiotic relationship exists between microorganisms (i.e., symbionts) and the termite itself in the termite's digestive tract. The symbionts are able to degrade cellulose, and the termite can degrade the lignocellulose in woody biomass. In fact, the symbionts live in the hindgut of termite's digestive tract. Our $\mathrm{pH}$ analysis revealed that the termite gut has an alkaline environment. Among the higher termites (Termitidae), alkaline gut regions are present in the Macrotermitidae, whose simple gut morphology resembles that of the lower termites. This phenomenon is independent of the insects' wood- or soil-feeding nature [12].

The alkalinity of the gut is believed to be an evolutionary adaptation to prevent precipitation of digestive enzymes and dietary proteins [13]. In addition, the digestive tract has the potential to adapt to phenolic compounds, recalcitrant organic matter, and secondary metabolites derived from plant cell walls and humic residues from soil materials. An alkaline environment would effectively solubilize those compounds.

The digestive tract of subterranean termites is divided into three major regions (i.e., the foregut, the 


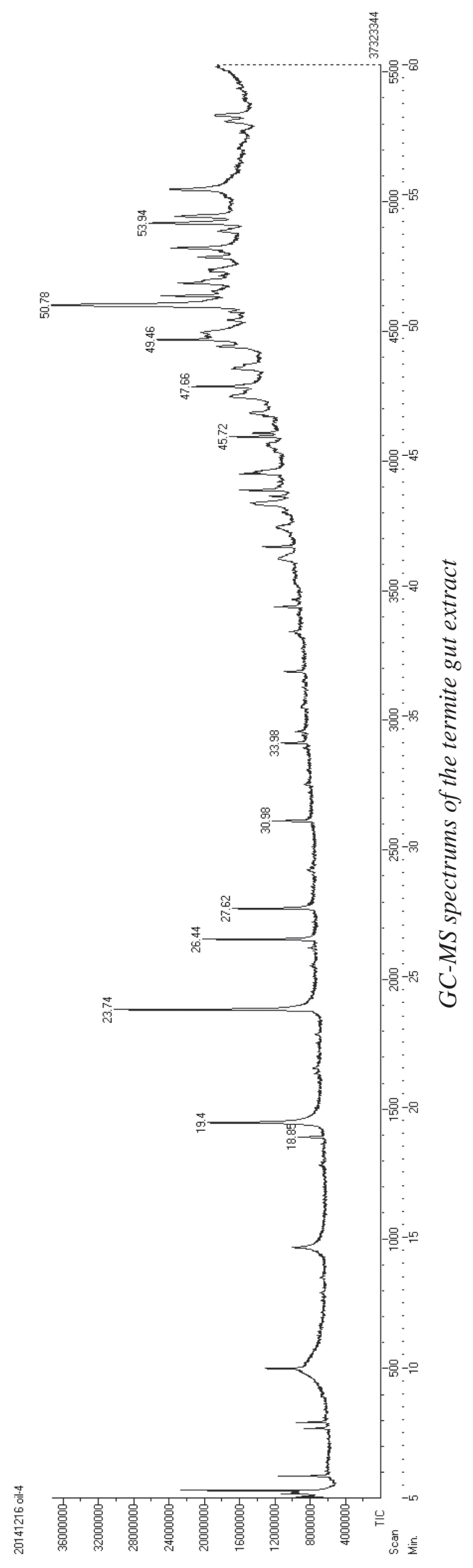

midgut, and the hindgut). The salivary glands are located in the foregut, which leads to the midgut as the junction between the foregut and hindgut. The hindgut is the major region of the digestive system and the site where the symbionts live [9]. The host and symbiont fractions in the termite digestive tract are working together to digest woody materials [14]. The researchers' analysis of glucose transporter gene expression together with glucose localization assays revealed that termites degrade the lignocellulosic compounds released by the symbiotic microfauna to obtain their energy.

The insects in the current study were obtained from natural habitats featuring soil and woody material. It is assumed that the termites' digestive tracts were filled with organic materials derived from both soil and woody matter. Soil and woody plants digested by termites are rich in phyto-compounds. Based on the GC-MS results from whole guts of M. gilvus subterranean termites, organosilicon compounds (i.e., dodecamethylcyclohexasiloxane, tetradecamethyl cyclohexasiloxane, hexadecamethyl cyclooctasiloxane, and octasiloxane, 1,1,3,3,5,5,7,7,9,9,11,11,13,13,15,15-hexadecamethyl) and the phytosterol $\beta$-sitosterol were present. Organosilicon compounds are organic compounds containing carbon-silicon bonds that are very poorly soluble in water. Silicon can be found on all sides of wood, over its entire surface; wood always contains a small amount of silica [15]. However, the natural amount of silica is too low to be detected by chemical analysis or by micrograph scanning [16]. Termites are able to digest the polymer of woody materials, but not the organosilicon compounds, to obtain glucose for energy. At high concentrations, the organosilicon compounds can be toxic for ter-

Major compounds of the termite gut extract based on GC-MS analysis

\begin{tabular}{|c|c|}
\hline $\begin{array}{c}\text { GC-MS } \\
\text { retention } \\
\text { time }\end{array}$ & Compounds \\
\hline 19.4 & Dodecamethylcyclohexasiloxane \\
\hline 23.74 & Tetradecamethyl cyclohexasiloxane \\
\hline 27.62 & Hexadecamethylcyclooctasiloxane \\
\hline 49.46 & $\begin{array}{l}\text { Octasiloxane, 1,1,3,3,5,5,7,7,9,9,11,11,13, } \\
\text { 13,15,15-hexadecamethyl }\end{array}$ \\
\hline 50.78 & $\beta$-sitosterol \\
\hline
\end{tabular}


mites. In fact, these compounds are synthesized in industry as water repellents and insecticides. The organosilicon compounds octamethylcyclotetrasiloxane (D4) decamethylcyclopentasiloxane (D5), and dodecamethylcyclohexasiloxane (D6) are high-production-volume chemicals used in household goods and personal maintenance systems. These applications make use of the physical properties of D6, such as its volatility, ease of spreading, clarity, compatibility with a wide range of other organic substances, and lubricating abilities. In household care products, much like personal care products, D6 is used as a base fluid or solvent for other larger molecules. It is used in a variety of products, including cleaning and washing products and polishes and waxes. There are no reports on the use of organosilicon compounds at nontoxic levels in termite metabolic pathways, and further analysis of this issue is needed.

In addition to the organosilicon components, the phytosterol $\beta$-sitosterol was also found in the termite gut. $\beta$-Sitosterol is the main unsaponifiable hydrophobic component in woody plants, and it is one of several phytosterols (plant sterols) with a chemical structure similar to cholesterol. In the termite intestinal tract, cholesterol is either directly obtained from woody matter or converted from another compound into cholesterol in the gut. It is interesting that we found a plant sterol ( $\beta$-sitosterol) in the termite gut that was not completely converted into cholesterol. This finding suggests that $\beta$-sitosterol has a role in the metabolism of subterranean termite [17]. In fact, sterol molecules and their intermediates support insect symbioses [18]. Some termites and other insects are incapable of producing sterol molecules de novo; therefore, they need to obtain the sterol from external sources, such as from soil or woody materials [19]. The sterol itself could benefit the symbionts in the termite gut. Sterol analysis is useful not only for determining nutrient sources for termites but also for identifying the metabolic intermediates that are formed in hormonal and microbial metabolism of sterols. The potencies of microbiota inside the termite intestinal tract have been studied by many researchers. Nobre and Aanen [19] had studied the symbiosis between termite gut microorganisms with fungus for substrate degradation, with the microorganisms providing the lignocellulolytic enzymes to degrade the plant materials. It seems that in various environments, the feeding sources of termites will vary as well, and the symbiosis between termites and symbionts will also differ. For example, Gautam and Henderson found that soil type and moisture level affect Coptotermes formonasus Shiraki activity and feeding behavior, such as exploratory tunneling activity [20].

Conclusions. Whole guts of M. gilvus subterranean termites had an alkaline $\mathrm{pH}$ of $8.83 \pm 0.31$. The alkaline condition plays an important role in the digestion process woody materials together with the microorganisms. GC-MS analysis showed five major compounds in the termite digestive tract. Four of them were organosilicon compounds obtained from the woody plant matter that were not involved in the termite metabolic pathway. The fifth compound was a phytosterol, $\beta$-sitosterol, that can be converted into cholesterol, which is a nutrient for insects and their symbionts.

Acknowledgments. This work was financially supported by the Research Collaboration Grant of Directorate General of Higher Education (DIKTI) through Semarang State University, Semarang, Indonesia.

Author Contributions: Niken Subekti conceived and designed the experiments; Niken Subekti and Priyantini Widyaningrum performed the experiments and contributed reagents/materials/analysis tools; Morina Adfa analyzed the data; Fidia Fibriana wrote the paper.

Conflicts of Interest: There are no pertinent commercial and other relationships that may be perceived as a potential source of conflict of interest. 


\section{ВИЗНАЧЕННЯ ОСНОВНИХ СПОЛУК В ЕКСТРАКТІ ШКТ ПІДЗЕМНИХ ТЕРМІТІВ Macrotermes gilvus Hagen ГХ-МС МЕТОДОМ}

N. Subekti ${ }^{1 *}$, F. Fibriana ${ }^{2}$, P. Widyaningrum ${ }^{1}$, M. Adfa $^{3}$

${ }^{1}$ Department of Biology, Faculty of Mathematics and Natural Sciences, Semarang State University, Indonesia; *e-mail: nikensubekti@mail.unnes.ac.id; ${ }^{2}$ Department of Integrated Sciences, Faculty of Mathematics and Natural Sciences, Semarang State University, Indonesia; e-mail: fibriana.f@mail.unnes.ac.id;

${ }^{3}$ Department of Chemistry, Faculty of Mathematics and Natural Sciences, Bengkulu University, Indonesia; e-mail: morinaadfa@yahoo.com

Перетравлення деревних компонентів у термітів відбувається завдяки наявності симбіонтів в їхньому кишечнику. У роботі проведено ГХ-МС аналіз основних сполук, що виявлені в екстракті ШКТ підземних термітів. I3 Macrotermes gilvus Hagen (робоча каста) вилучали цілком ШКТ, подрібнювали і проводили екстрагування метанолом. Показано, що травний тракт у термітів має лужне сере-

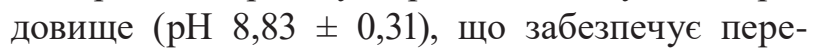
травлення лігноцелюлозних біомас i також сприяє солюбілізації фенольних та інших стійких сполук, що утворюються внаслідок деполімеризації деревних компонентів. За допомогою ГХ-МС аналізу встановлено, що ШКТ термітів містить гідрофобні кремнійорганічні сполуки, такі як: додекаметилциклогексасилоксан, тетрадекаметилциклогексасилоксан, гексадекаметилциклооктасилоксан і октасилоксан, $1,1,3,3,5,5,7,7,9,9,11,11,13,13,15,15$-гексадекаметил, крім того також виявлено фітостерол $\beta$-ситостерол. Для з'ясування значення цих водонерозчинних сполук у травленні термітів необхідне проведення подальшого аналізу.

К лючов і слова: Macrotermes gilvus Hagen, деградація деревних матеріалів, шлунково-кишковий тракт термітів, ГХ-МС метод.

\section{ОПРЕДЕЛЕНИЕ ОСНОВНЫХ СОЕДИНЕНИЙ В ЭКСТРАКТЕ ЖКТ ПОДЗЕМНЫХ ТЕРМИТОВ Macrotermes gilvus Hagen ГX-МС МЕТОДОМ}

\section{N. Subekti ${ }^{1 *}$, F. Fibriana ${ }^{2}$, P. Widyaningrum ${ }^{1}$, M. Adfa ${ }^{3}$}

${ }^{1}$ Department of Biology, Faculty of Mathematics and Natural Sciences, Semarang State University, Indonesia; *e-mail: nikensubekti@mail.unnes.ac.id; ${ }^{2}$ Department of Integrated Sciences, Faculty of Mathematics and Natural Sciences, Semarang State University, Indonesia; e-mail: fibriana.f@mail.unnes.ac.id;

${ }^{3}$ Department of Chemistry, Faculty of Mathematics and Natural Sciences, Bengkulu University, Indonesia; e-mail: morinaadfa@yahoo.com

Переваривание древесных компонентов у термитов происходит благодаря наличию симбионтов в их кишечнике. В работе проведен ГХ-МС анализ основных соединений в экстракте ЖКТ подземных термитов. Из Macrotermes gilvus Hagen (рабочая каста) извлекали ЖКТ целиком, измельчали и проводили экстрагирование метанолом. Показано, что ЖКТ термитов имеет щелочную среду ( $\mathrm{HH} 8,83 \pm 0,31)$, что обеспечивает переваривание лигноцеллюлозных биомасс и также способствует солюбилизации фенольных и других устойчивых соединений, образующихся в результате деполимеризации древесных компонентов. ГХ-МС анализ показал, что ЖКТ термитов содержит гидрофобные кремнийорганические соединения, такие как: додекаметилциклогексасилоксан, тетрадекаметилциклогексасилоксан, гексадекаметилциклооктасилоксан и октасилоксан, 1,1,3,3,5,5,7,7,9,9,11,11,13,13,15,15-гексадекаметил, кроме того также обнаружен фитостерол $\beta$-ситостерол. Для выяснения значения этих водонерастворимых соединений в пищеварении термитов необходимо проведение дальнейшего анализа.

К л ючевы е с лов в: Macrotermes gilvus Hagen, деградация древесных компонентов, желудочно-кишечный тракт термитов, ГХ-МС метод. 


\section{References}

1. Donovan SE, Eggleton P, Bignell DE. Gut content analysis and a new feeding group classification of termites. Ecol Entomol. 2001; 26(4): 356-366.

2. Ohkuma M, Brune A. Diversity, structure, and evolution of the termite gut microbial community. In Biology of Termites: A Modern Synthesis; Bignell DE, Roisin Y, Lo N., Eds.; Springer: New York, NY, 2011; pp. 413-438.

3. Holt JA, Lepage M. Termite and soil properties. In Termites: Evolution, Sociality, Symbioses, Ecology; Abe T, Bignell DE, Higashi M., Eds.; Kluwer Academic Publisher: London, 2000; P. 389-408.

4. Ni J, Tokuda G. Lignocellulose-degrading enzymes from termites and their symbiotic microbiota. Biotechnol Adv. 2013; 31(6): 838850.

5. Watanabe H, Tokuda G. Cellulolytic systems in insects. Annu Rev Entomol. 2010;55: 609-632.

6. Brune A, Emerson D, Breznak JA. The Termite Gut Microflora as an Oxygen Sink: Microelectrode Determination of Oxygen and $\mathrm{pH}$ Gradients in Guts of Lower and Higher Termites. Appl Environ Microbiol. 1995; 61(7): 2681-2687.

7. Köhler T, Dietrich C, Scheffrahn RH, Brune A. High-resolution analysis of gut environment and bacterial microbiota reveals functional compartmentation of the gut in wood-feeding higher termites (Nasutitermes spp.). Appl Environ Microbiol. 2012; 78(13): 4691-4701.

8. Scharf ME, Boucias DG. Potential of termitebased biomass pre-treatment strategies for use in bioethanol production. Insect Sci. 2010; 17(3): 166-174.

9. Scharf ME, Tartar A. Termite digestomes as sources for novel lignocellulases. Biofuels Bioprod Biorefin. 2008; 2(6): 540-552.

10. Wheeler MM, Tarver MR, Coy MR, Scharf ME. Characterization of four esterase genes and esterase activity from the gut of the termite Reticulitermes flavipes. Arch Insect Biochem Physiol. 2010; 73(1): 30-48.
11. Brune A, Kühl M. pH profiles of the extremely alkaline hindguts of soil-feeding termites (Isoptera: Termitidae) determined with microelectrodes. J Insect Physiol. 1996; 42(1112): 1121-1127.

12. Felton GW, Duffey SS. Reassessment of the role of gut alkalinity and detergency in insect herbivory. J Chem Ecol. 1991; 17(9): 1821-1836.

13. Karl ZJ. The termite digestome: understanding the digestive physiology involved in lignocellulosic biomass degradation. Open Access Dissertations. 2013. Paper 131. Regime of access: http://docs.lib.purdue.edu/open access_dissertations.

14. Grimshaw HM, Parkinson JA, Allen SE. Chemical Analysis of Ecological Materials. Blackwell Scientific Publications: Oxford, UK, 1974; $565 \mathrm{p}$.

15. De Vetter L, Cnudde V, Masschaele B, Jacobs PJS, Van Acker J. Detection and distribution analysis of organosilicon compounds in wood by means of SEM-EDX and micro-CT. Mater Charac. 2006; 56(1): 39-48.

16. Cmelik SHW. Composition of the sterol fraction from various organs of termite queens. Insect Biochem. 1971; 1(3): 299-301.

17. Kobune S, Kajimura H, Masuya H, Kubono T. Symbiotic fungal flora in leaf galls induced by Illiciomyia yukawai (Diptera: Cecidomyiidae) and in its mycangia. Microb Ecol. 2012; 63(3): 619-627.

18. Behmer ST, Nes D. Insect Sterol Nutrition and Physiology: A Global Overview. Advances in Insect Physiology. Elsevier: LOCATION, 2003; pp. 1-72.

19. Nobre T, Aanen DK. Fungiculture or Termite Husbandry? The Ruminant Hypothesis. Insects. 2012; 3(1): 307-323.

20. Gautam BK, Henderson G. Laboratory Study of the Influence of Substrate Type and Temperature on the Exploratory Tunneling by Formosan Subterranean Termite. Insects. 2012; 3(3): 629639. 